\title{
ANALISIS EKONOMI PAKAN TERNAK TERFERMENTASI BERBASIS LIMBAH AGROINDUSTRI PISANG DI KABUPATEN LUMAJANG
}

\section{ECONOMICS ANALYSIS OF FERMENTED FEED BASED ON BANANA AGROINDUSTRY WASTE IN DISTRICT OF LUMAJANG}

\author{
Shanti Akhiriani ${ }^{1}$, Soetriono ${ }^{2}$, Nurhayati ${ }^{3}$ \\ ${ }^{1}$ Jurusan Agribisnis, Fakultas Pertanian, Universitas Lumajang \\ ${ }^{2}$ Jurusan Agribisnis, Fakultas Pertanian, Universitas Jember \\ ${ }^{3}$ Jurusan Teknologi Hasil Pertanian, Fakultas Teknologi Pertanian, Universitas Jember \\ email: akhiriani_shan@yahoo.com
}

\begin{abstract}
ABSTRAK
Pakan ternak terfermentasi merupakan produk bernilai ekonomi yang bisa dihasilkan dari salah satu limbah agroindustri pisang, yaitu kulit pisang. Penelitian ini bertujuan untuk mengetahui: (1) pendapatan dan efisiensi usaha pada agroindustri pakan ternak terfermentasi dari kulit pisang; dan (2) nilai tambah pada pemanfaatan kulit pisang menjadi pakan ternak terfermentasi. Penelitian ini menggunakan pendekatan metode deskriptif dan analitik. Pengambilan data pada penelitian ini bersumber dari data primer dan data sekunder. Hasil penelitian menunjukkan bahwa agroindustri pakan ternak terfermentasi menguntungkan dan efisien untuk diusahakan berdasarkan analisis pendapatan dan nilai $\mathrm{R} / \mathrm{C}$ ratio, yaitu pendapatan agroindustri pakan ternak terfermentasi untuk produksi setiap hari sejumlah Rp 567.179,00 dengan nilai R/C ratio 1,54. Agroindustri pakan ternak terfermentasi memberikan nilai tambah positif untuk setiap kilogram bahan baku yang digunakan, yaitu sebesar Rp 393,48 atau 62,98\% dari nilai produk.
\end{abstract}

Kata kunci: efisiensi usaha, kulit pisang, nilai tambah, pakan ternak terfermentasi, pendapatan.

\begin{abstract}
Fermented fodder is an economic value product that can be produced from one of the waste of banana agroindustry, namely banana peel. This study aims to determine: (1) income and business efficiency in fermented animal feed agro industry from banana peel; and (2) added value on the utilization of banana peels into fermented fodder. This research use descriptive and analytic method approach. Data retrieval in this research comes from primary data and secondary data. The results showed that fermented animal feed agroindustry was profitable and efficient to be cultivated based on income analysis and $R / C$ ratio, ie fermented animal feed agro industry income for daily production amounting to IDR 567,179.00 with $R$ / C ratio 1.54. Fermented animal feed agroindustry gives positive value for each kilogram of raw materials used, that is IDR 393,48 or $62,98 \%$ from product value.
\end{abstract}

Keywords: business efficiency, banana skin, added value, fermented animal feed, income.

\section{PENDAHULUAN}

Pisang adalah tumbuhan monokotil yang termasuk dalam familia Musaceae yang berasal dari Asia Tenggara. Di Indonesia, pisang merupakan buah yang paling banyak dikonsumsi dibandingkan 
dengan buah-buahan lain. Sebagai komoditas unggulan, pisang merupakan buah yang mudah didapat, memiliki nilai ekonomi, budaya, serta nilai gizi yang tinggi. Buah pisang sangat prospektif sebagai bahan baku industri. Selain karena kemudahan dalam mendapatkan bahan baku, berbagai produk dapat diolah dari buah pisang, antara lain keripik, sale, manisan, dodol, dan tepung pisang.

Pemanfaatan buah pisang yang besar untuk berbagai jenis makanan, akan menghasilkan limbah berupa kulit pisang. Bobot kulit pisang mencapai 38,8\% dari buahnya (Santoso, 1995), dengan demikian kulit pisang merupakan limbah agroindustri pisang dengan volume yang cukup besar. Kulit pisang belum dimanfaatkan secara optimal, hanya dibuang sebagai limbah organik atau dalam bentuk segar digunakan sebagai bahan pakan ternak kambing.

Bahan pakan adalah sesuatu yang dapat dimakan oleh ternak, dicerna dan diserap baik sebagian maupun seluruhnya tanpa menimbulkan keracunan pada ternak yang bersangkutan. Bahan pakan dapat berasal dari tumbuh-tumbuhan maupun dari hewan. Ternak ruminansia lebih memerlukan bahan pakan yang berasal dari tumbuh-tumbuhan, sedangkan ternak non-ruminansia memerlukan bahan pakan baik dari tumbuh-tumbuhan maupun hewan (Sukria dan Krisnan, 2009).

Kulit pisang di Kabupaten Lumajang pada umumnya hanya dimanfaatkan sebagai pakan ternak kambing pendamping hijauan makanan ternak (HMT). Hal ini dilakukan mengingat ketersediaan hijauan makanan ternak secara kuantitas terbatas terutama pada saat musim kemarau. Namun demikian, kulit pisang sebagai pakan yang diberikan pada ternak selama ini tanpa dilakukan penanganan dan pengolahan lebih lanjut untuk meningkatkan nilai gizi kulit pisang tersebut. Menurut Udjianto (2003), penggunaan limbah pisang fermentasi sebagai pakan ternak mempunyai prospek yang baik karena dapat meningkatkan nilai gizi limbah pisang seperti protein kasar $14,88 \%$, serat kasar $11,43 \%$ dan lemak 7\%. Sedangkan Udjianto et al. (2005) menyatakan bahwa penambahan 5\% kulit pisang fermentasi ke dalam ransum ayam pedaging, menghasilkan kinerja yang positif pada pertumbuhan ayam broiler dengan konversi ransum 1,74. Pada pemeliharaan yang besar, selisih harga ransum sebesar Rp 20,- akan menambah pendapatan sangat nyata.

Pengolahan kulit pisang menjadi pakan ternak terfermentasi akan memberikan nilai tambah per satuan kilogram kulit pisang yang diolah. Nilai 
tambah adalah selisih antara pendapatan yang diperoleh dari penjualan/ jasa dan biaya untuk pembelian bahan-bahan yang diperlukan guna menghasilkan barangbarang atau jasa tersebut (Manulang, 1990). Menurut Hayami (1987), nilai tambah diartikan sebagai nilai keuntungan yang diperoleh dari nilai produk olahan (bahan jadi) dikurangi nilai bahan baku dan biaya produksi selain tenaga kerja (intermediate cost) yang digunakan dalam proses tersebut dalam satuan kilogram bahan baku.

Sebelum mendirikan agroindustri pakan ternak terfermentasi dari kulit pisang, diperlukan suatu kajian ekonomi untuk menganalisis apakah agroindustri tersebut menguntungkan dan efisien untuk diusahakan. Berhasil atau tidaknya suatu kegiatan usaha, antara lain tergantung dari hasil analisis pendapatan dan efisiensi usaha yang dilakukan. Berdasarkan latar belakang permasalahan di atas, perlu dilakukan penelitian yang mengkaji pendapatan, efisiensi usaha dan nilai tambah dari pemanfaatan kulit pisang menjadi pakan ternak terfermentasi. Hasil penelitian ini diharapkan berguna dalam usaha pengembangan alternatif baru sumber pakan ternak terfermentasi dengan memanfaatkan kulit pisang sebagai bahan bakunya yang selama ini tersedia cukup banyak tetapi kurang dimanfaatkan menjadi produk yang bernilai ekonomi tinggi.

Penelitian ini bertujuan untuk mengetahui: (1) Pendapatan dan efisiensi usaha pada agroindustri pakan ternak terfermentasi dari kulit pisang; dan (2) Nilai tambah pada pemanfaatan kulit pisang menjadi pakan ternak terfermentasi.

\section{METODE PENELITIAN}

Penelitian dilakukan di sentra produksi pisang Kabupaten Lumajang, yaitu Kecamatan Senduro. Lokasi tersebut dipilih secara sengaja (Purposive Sampling) dengan pertimbangan bahwa Kecamatan Senduro:

1. Merupakan salah satu sentra budidaya pisang di Kabupaten Lumajang;

2. Terdapat cukup banyak perusahaan agroindustri berbahan baku pisang sehingga menghasilkan banyak kulit pisang;

3. Memiliki potensi populasi ternak yang cukup besar sehingga membutuhkan alternatif baru sumber pakan ternak dengan bahan baku lokal yang mudah diperoleh.

Penelitian ini menggunakan pendekatan metode deskriptif dan analitik. 
Data yang diambil untuk analisis ekonomi merupakan hasil dari studi literatur dengan pertimbangan bahwa di Kecamatan Senduro belum pernah dilakukan pengolahan pakan ternak terfermentasi berbahan baku kulit pisang. Data pendukung diperoleh dari observasi lapang, informasi dari informan kunci (peneliti terdahulu, penyuluh pertanian, distributor dan sebagainya), serta ditunjang oleh beberapa studi pustaka. Pengambilan data pada penelitian ini bersumber dari data primer dan data sekunder (kualitatif dan kuantitatif).

Untuk menguji hipotesis pertama, dilakukan analisis pendapatan untuk mengetahui pendapatan yang diperoleh dari agroindustri pakan ternak terfermentasi. Menurut Soekartawi (2002), penerimaan adalah perkalian antara produksi dengan harga jual, biaya adalah semua pengeluaran yang dipergunakan dalam suatu usaha, dan pendapatan adalah selisih antara penerimaan dan pengeluaran.

Untuk menghitung pendapatan yang diperoleh dari usaha agroindustri pakan ternak terfermentasi, digunakan pendekatan analisis statistik dengan tabulasi dan rumus sebagai berikut:

$$
\begin{array}{ll}
\pi & =\mathrm{TR}-\mathrm{TC} \\
\mathrm{TR} & =\mathrm{Y} . \mathrm{PY}
\end{array}
$$

Keterangan:

$$
\begin{aligned}
\pi & =\text { Profit } \\
\mathrm{TR} & =\text { Total Revenue (Penerimaan } \\
& \text { Total) } \\
\mathrm{TC} & =\text { Total Cost (Biaya Total) } \\
\mathrm{Y} & =\text { Total Output (produk yang } \\
& \text { dihasilkan) } \\
\mathrm{PY} & =\text { Harga Produk/ Kg }
\end{aligned}
$$

Untuk menghitung efisiensi guna mengetahui apakah agroindustri pakan ternak terfermentasi tersebut menguntungkan atau tidak, dapat digunakan rumus sebagai berikut:

$$
\mathrm{R} / \mathrm{C}=\frac{\text { Penerimaan Total }}{\text { Biaya Total }}
$$

Dengan kriteria sebagai berikut:

a. $\mathrm{R} / \mathrm{C}$ ratio > 1, maka agroindustri tersebut efisien.

b. $\mathrm{R} / \mathrm{C}$ ratio $=1$, maka agroindustri tersebut impas.

c. $\mathrm{R} / \mathrm{C}$ ratio < 1, maka agroindustri tersebut tidak efisien.

Untuk menguji hipotesis kedua, dilakukan analisis nilai tambah menggunakan metode analisis Hayami. Kegiatan mengolah bahan baku kulit pisang menjadi produk olahan seperti pakan ternak terfermentasi mengakibatkan meningkatnya nilai tambah kulit pisang. Untuk melihat pertambahan nilai dari kulit pisang serta balas jasa yang diterima pelaku usaha, dihitung menggunakan metode analisis Hayami yang umum digunakan untuk 
Akhiriani dkk: Analisis ekonomi pakan ternak terfermentasi ....

menganalisis nilai tambah pada subsistem

pengolahan atau produksi sekunder.

Kerangka analisis perhitungan nilai tambah metode Hayami dapat dilihat pada Tabel 1.

Tabel 1. Analisis Perhitungan Nilai Tambah Metode Hayami

\begin{tabular}{|c|c|c|}
\hline No. & Variabel & Nilai \\
\hline & Output, Input, Harga & \\
\hline 1 & Output/ total produksi (Kg/periode) & A \\
\hline 2 & Input bahan baku ( $\mathrm{Kg} /$ periode $)$ & $\mathrm{B}$ \\
\hline 3 & Input Tenaga kerja (HOK/ periode) & $\mathrm{C}$ \\
\hline 4 & Faktor konversi (1) / (2) & $\mathrm{D}=\mathrm{A} / \mathrm{B}$ \\
\hline 5 & $\begin{array}{l}\text { Koefesien tenaga kerja } \\
(3) /(2)\end{array}$ & $\mathrm{E}=\mathrm{C} / \mathrm{B}$ \\
\hline 6 & Harga produk $(\mathrm{Rp} / \mathrm{Kg})$ & $\mathrm{F}$ \\
\hline 7 & Upah rata-rata tenaga kerja per HOK (Rp/HOK) & $\mathrm{G}$ \\
\hline & Pendapatan & \\
\hline 8 & Harga input bahan baku (Rp/Kg) & $\mathrm{H}$ \\
\hline 9 & Sumbangan input lain $(\mathrm{Rp} / \mathrm{Kg})$ & $\mathrm{I}$ \\
\hline 10 & Nilai produk (4)x(6) $(\mathrm{Rp} / \mathrm{Kg})$ & $\mathrm{J}=\mathrm{D} X \mathrm{~F}$ \\
\hline 11 & $\begin{array}{l}\text { a. Nilai tambah (10)-(8)- } \\
\text { (9) ( Rp / Kg) } \\
\text { b. Rasio nilai tambah }(11 \mathrm{a}) /(10)(\%)\end{array}$ & $\begin{array}{l}\mathrm{K}=\mathrm{J}-\mathrm{H}-\mathrm{I} \\
\mathrm{L} \%=(\mathrm{K} / \mathrm{J}) \%\end{array}$ \\
\hline 12 & $\begin{array}{l}\text { a. Pendapatan Tenaga kerja }(\mathrm{Rp} / \mathrm{Kg}) \\
\text { b. Imbalan tenaga kerja } \\
\quad(12 \mathrm{a}) /(11 \mathrm{a})(\%)\end{array}$ & $\begin{array}{l}\mathrm{M}=\mathrm{E} X \mathrm{G} \\
\mathrm{N} \%=(\mathrm{M} / \mathrm{K}) \%\end{array}$ \\
\hline 13 & $\begin{array}{l}\text { a. Pendapatan (11a)-(12a) }(\mathrm{Rp} / \mathrm{Kg}) \\
\text { b. Tingkat pendapatan } \\
\quad(13 \mathrm{a}) /(11 \mathrm{a})(\%)\end{array}$ & $\begin{array}{l}\mathrm{O}=\mathrm{K}-\mathrm{M} \\
\mathrm{P} \%=(\mathrm{O}-\mathrm{K}) \%\end{array}$ \\
\hline 14 & $\begin{array}{l}\text { Balas Jasa Untuk Faktor Produksi } \\
\text { Marjin }(10)-(8)(\mathrm{Rp} / \mathrm{Kg}) \\
\text { a. Pendapatan tenaga } \\
\text { kerja }(12 \mathrm{a}) /(14)(\%) \\
\text { b. Sumbangan input lain } \\
\quad(9) /(4)(\%) \\
\text { c. Pendapatan } \\
\text { perusahaan }(13 \mathrm{a}) / \\
\quad(14)(\%)\end{array}$ & $\begin{array}{l}\mathrm{Q}=\mathrm{J}-\mathrm{H} \\
\mathrm{R} \%=(\mathrm{M} / \mathrm{Q}) \% \\
\mathrm{~S} \%=(\mathrm{I} / \mathrm{Q}) \% \\
\mathrm{~T} \%=(\mathrm{O} / \mathrm{Q}) \%\end{array}$ \\
\hline
\end{tabular}

Sumber : Hayami et. al ( 1987 )

HASIL DAN PEMBAHASAN
Pendapatan dan Efisiensi Usaha pada Agroindustri Terfermentasi
Pakan

Ternak 
Agroindustri pakan ternak terfermentasi merupakan jenis usaha alternatif yang memanfaatkan kulit pisang sebagai bahan bakunya. Pengusaha atau bahkan masyarakat umum membutuhkan informasi awal apakah agroindustri tersebut menguntungkan dan efisien untuk diusahakan. Agroindustri pakan ternak terfermentasi menggunakan bahan baku berupa kulit pisang segar yang diberi perlakuan fermentasi dengan menambahkan sejumlah komponen bahan pendukung untuk aktivasi mikroba inokulan. Komponen biaya, penerimaan, pendapatan dan efisiensi usaha pada agroindustri pakan ternak terfermentasi selengkapnya pada Tabel 2.

Tabel 2. Biaya, Penerimaan, Pendapatan dan Efisiensi Usaha pada Agroindustri Pakan Ternak Terfermentasi per Hari

\begin{tabular}{lccccc}
\hline Uraian & Satuan & Jumlah & $\begin{array}{c}\text { Harga/ satuan } \\
(\mathrm{Rp})\end{array}$ & Nilai (Rp) & $\%$ \\
\hline
\end{tabular}

\section{Biaya Variabel:}

1) Kulit pisang

2) Bahan pendukung:

a) Trichoderma viride

b) Gula

c) Urea

d) NPK

3) Solar

4) Karung kemasan

5) Biaya labeling

6) Biaya pemasaran

7) Tenaga produksi

Sub Jumlah kg

liter

$\mathrm{kg}$

$\mathrm{kg}$

$\mathrm{kg}$

liter

lembar

lembar

hari

orang
2.600

1,3

2,6

2,6

1,3

15,77

22

22

1

4
100

30.000

12.000

4.500

4.550

10.500

3.000

1.000

20.000

48.000
260.000

39.000

31.200

11.700

5.915

165.636

66.000

22.000

20.000

192.000

813.451

76,94

\section{Biaya Tetap:}

1) Manajer

2) Tenaga administrasi

3) Biaya penyusutan

4) Biaya pemeliharaan

orang
orang
hari
hari

68.000

68.000

48.000

48.000

76.076

76.076

51.794

51.794

Sub Jumlah

\section{Total Biaya (TC)}

243.870

\section{Penerimaan :}

Nilai penjualan pakan ternak terfermentasi

$\mathrm{kg}$
1.083 1.500 1.624 .500

\begin{tabular}{llc}
\hline Total penerimaan $($ TR) & $\mathrm{Rp}$ & $\mathbf{1 . 6 2 4 . 5 0 0}$ \\
\hline Pendapatan $($ TR-TC) & $\mathrm{Rp}$ & $\mathbf{5 6 7 . 1 7 9}$ \\
\hline R/C Ratio & & $\mathbf{1 , 5 4}$
\end{tabular}

Sumber: Data Primer Diolah, 2014 dan tenaga produksi, adalah biaya bahan

Komponen biaya variabel yang dibutuhkan pada agroindustri pakan ternak terfermentasi selain bahan baku pendukung yang terdiri dari mikroba

Trichoderma viride, gula, pupuk urea dan 
NPK. Input lain yang juga dibutuhkan adalah bahan bakar berupa solar, karung

kemasan dan biaya labelling. Komponen biaya tetap terdiri dari gaji manajer dan tenaga administrasi, biaya penyusutan dan pemeliharaan bangunan pabrik dan mesin/ peralatan serta biaya pemasaran. Total biaya yang dikeluarkan untuk agroindustri pakan ternak terfermentasi setiap kali produksi (per hari) sejumlah $\mathrm{Rp} \quad 1.057 .179,00$ dengan persentase kebutuhan mencapai $76,94 \%$ dari total biaya yang dibutuhkan.

Perusahaan pakan ternak terfermentasi dapat menghasilkan produk akhir berupa pakan ternak terfermentasi berbahan baku kulit pisang dalam bentuk serbuk kering sejumlah $1.083 \mathrm{~kg}$ per hari atau pada setiap kali produksi. Jika harga jual produk akhir yang ditetapkan sebesar $\mathrm{Rp} 1.500,00 / \mathrm{kg}$, maka penerimaan perusahaan adalah Rp 1.624.500,00 per hari. Agroindustri pakan ternak terfermentasi tidak menghasilkan produk sampingan yang masih bisa dimanfaatkan atau dijual, sehingga total penerimaan hanya diperoleh dari penjualan pakan ternak terfermentasi.

Tabel 2 menunjukkan bahwa agroindustri pakan ternak terfermentasi menguntungkan dan efisien untuk diusa- hakan, hal ini terlihat dari nilai pendapatan yang diperoleh untuk setiap produksi (per hari) adalah positif, yaitu $\mathrm{Rp} 567.179,00$ dan $\mathrm{R} / \mathrm{C}$ ratio 1,54. Pendapatan diperoleh dari total penerimaan (TR) sebesar $\mathrm{Rp}$ 1.624.500,00 dikurangi total biaya (TC) sebesar Rp 1.057.321,00; sedangkan nilai efisiensi usaha ( $\mathrm{R} / \mathrm{C}$ ratio) didapatkan dari total penerimaan (TR) dibandingkan dengan total biaya (TC). Nilai R/C ratio sebesar 1,54 menunjukkan bahwa setiap Rp 1,00 biaya yang dikeluarkan per satuan unit akan memperoleh penerimaan sebesar Rp 1,54 dengan besaran pendapatan mencapai Rp 0,54. Hal ini menunjukkan bahwa agroindustri pakan ternak terfermentasi efisien untuk diusahakan karena nilai $\mathrm{R} / \mathrm{C}$ ratio yang didapatkan lebih dari satu $(\mathrm{R} / \mathrm{C}>1)$.

\section{Nilai Tambah Agroindustri Pakan Ternak Terfermentasi}

Konsep nilai tambah adalah suatu pengembangan nilai yang terjadi karena adanya input yang diperlakukan pada suatu komoditas. Input yang menyebabkan terjadinya nilai tambah dari suatu komoditas dapat dilihat dari adanya perubahan-perubahan pada komoditas tersebut, yaitu perubahan bentuk, tempat, dan waktu. Nilai tambah menggambarkan imbalan bagi tenaga kerja, modal dan manajemen. Tujuan dari 
analisis nilai tambah adalah untuk mengukur balas jasa yang diterima pelaku sistem (pengolah) dan kesempatan kerja yang dapat diciptakan oleh sistem tersebut.

Proses pengolahan kulit pisang menjadi pakan ternak terfermentasi menyebabkan adanya nilai tambah pada komoditas tersebut, sehingga harga jual pakan ternak terfermentasi menjadi lebih tinggi daripada harga jual kulit pisang. Analisis nilai tambah dilakukan mulai dari pengadaan bahan baku berupa kulit pisang hingga menjadi produk pakan ternak terfermentasi yang siap dipasarkan. Analisis nilai tambah bertujuan untuk mengetahui besarnya nilai tambah, imbalan tenaga kerja, imbalan bagi modal dan manajemen dari setiap kilogram kulit pisang yang diolah menjadi pakan ternak terfermentasi.

Proses produksi pakan ternak terfermentasi memerlukan input utama berupa kulit pisang sebanyak 2.600 kilogram per hari dan tenaga kerja sebanyak 4 (empat) orang yang bekerja selama 8 jam sehari, sehingga jumlah hari orang kerja adalah 4 HOK. Sumbangan input lain yang dibutuhkan pada setiap kali proses produksi terdiri dari bahan pendukung untuk aktivasi mikroba inokulan, bahan bakar berupa solar dan biaya pengemasan. Jumlah sumbangan input lain pada agroindustri pakan ternak terfermentasi sebesar Rp 131,33/ kg kulit pisang yang diolah. Komponen sumbangan input lain selengkapnya pada Tabel 3.

Tabel 3. Sumbangan Input Lain pada Agroindustri Pakan Ternak Terfermentasi

\begin{tabular}{|c|c|c|c|}
\hline \multirow{2}{*}{ Komponen biaya } & \multicolumn{3}{|c|}{ Kebutuhan } \\
\hline & Jumlah & Harga (Rp/unit) & Nilai (Rp) \\
\hline 1. Trichoderma viride (liter) & 1,3 & 30.000 & 39.000 \\
\hline 2. Gula (kg) & 2,6 & 12.000 & 31.200 \\
\hline 3. Urea $(\mathrm{kg})$ & 2,6 & 4.500 & 11.700 \\
\hline 4. NPK $(\mathrm{kg})$ & 1,3 & 4.550 & 5.915 \\
\hline 5. Solar (liter) & 15,77 & 10.500 & 165.636 \\
\hline 6. Karung kemasan (lembar) & 22 & 4.000 & 88.000 \\
\hline Jumlah & & & 341.451 \\
\hline Sumbangan input lain/ kg bahan baku & & & 131,33 \\
\hline
\end{tabular}

Sumber: Data diolah, 2014.

Tabel 4. Nilai Tambah Agroindustri Pakan Ternak Terfermentasi

\begin{tabular}{clr}
\hline No. & \multicolumn{1}{c}{ Variabel } & Nilai \\
\hline & Output, Input, Harga & $1.083,00$ \\
1 & Output/ total produksi (Kg / hari) & $2.600,00$ \\
2 & Input bahan baku (Kg / hari) & 4,00 \\
3 & Input tenaga kerja ( HOK / hari) & 0,42 \\
4 & Faktor konversi (1) / (2) & 0,0015 \\
5 & Koefesien tenaga kerja (3) / (2) & $1.500,00$ \\
6 & Harga produk ( Rp / Kg) & $48.000,00$ \\
7 & Upah rata-rata tenaga kerja per HOK ( Rp / HOK) & 100,00 \\
& Pendapatan & 131,33 \\
9 & Harga input bahan baku ( Rp / Kg) & 624,81
\end{tabular}




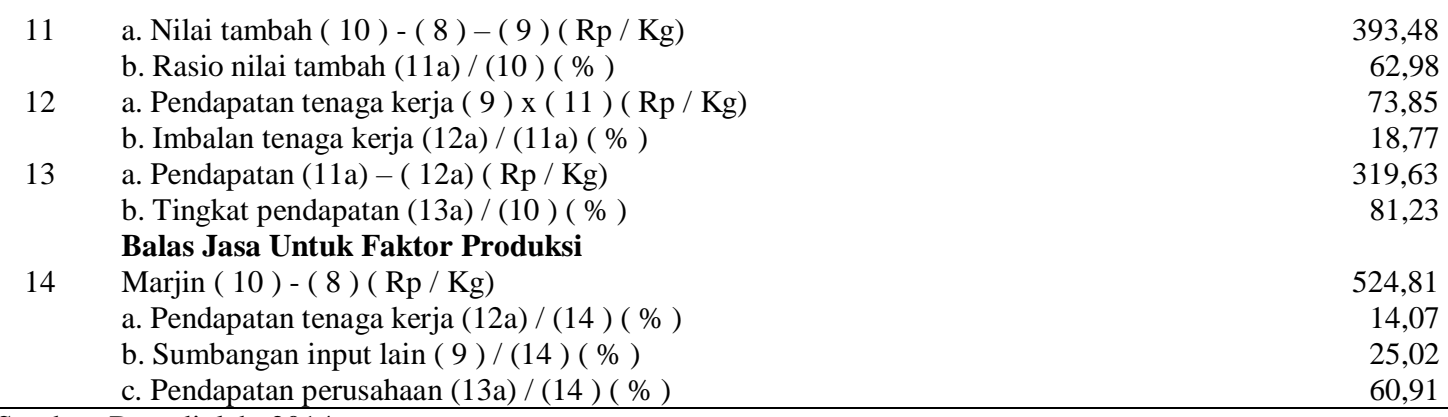
Sumber: Data diolah, 2014.

Tabel 3 menunjukkan bahwa sumbangan input lain pada agroindustri pakan ternak terfermentasi antara lain terdiri dari mikroba Trichoderma viride, gula, pupuk urea dan pupuk NPK. Keempat komponen bahan pendukung tersebut dibutuhkan dalam proses aktivasi mikroba inokulan. Proses aktivasi mikroba tersebut dilakukan dengan tujuan selain untuk mengembangbiakkan mikroba inokulan, juga untuk menghemat biaya produksi karena bibit mikroba inokulan Trichoderma viride dijual di pasaran dengan harga Rp30.000,00 per liter, sedangkan kebutuhan dalam satu kali produksi untuk memfermentasi 2.600 $\mathrm{kg}$ kulit pisang segar cukup banyak. Analisis nilai tambah pada agroindustri pakan ternak terfermentasi selengkapnya pada Tabel 4.

Dasar perhitungan dalam analisis nilai tambah agroindustri pakan ternak terfermentasi per satuan bahan baku adalah satu kilogram kulit pisang. Harga kulit pisang yang digunakan pada perhitungan nilai tambah ini adalah harga beli dari pengusaha agroindustri pisang di Kabupaten Lumajang, yaitu Rp 100,00 per kilogram, sedangkan harga produk didasarkan pada harga jual pakan ternak terfermentasi ke konsumen sebesar Rp1.500,00 per kilogram. Penentuan harga jual produk ditetapkan berdasarkan biaya (cost based pricing).

Tabel 4 diatas menunjukkan bahwa kapasitas produksi pakan ternak terfermentasi adalah sebesar 1.083 kilogram per hari. Nilai faktor konversi dihitung berdasarkan pembagian antara nilai output yang dihasilkan dengan nilai input yang digunakan. Untuk menghasilkan sejumlah produk tersebut dibutuhkan kulit pisang sebanyak 2.600 kilogram, sehingga faktor konversi adalah 0,42; artinya setiap satu kilogram kulit pisang yang diolah akan menghasilkan 0,42 kilogram pakan ternak terfermentasi.

Tenaga kerja yang dibutuhkan dalam pengolahan pakan ternak terfermentasi berbahan baku kulit pisang adalah 4 orang tenaga kerja, keempat 
tenaga kerja tersebut adalah laki-laki. Upah yang dibayarkan sebesar Rp 48.000,00 per Hari Orang Kerja (HOK) sesuai dengan Upah Minimum Kabupaten Lumajang berdasarkan Peraturan Gubernur Jawa Timur Nomor 72 Tahun 2012. Tenaga kerja tersebut tidak selalu bekerja bersama dalam satu waktu, masing-masing mempunyai tugas yang berbeda-beda. Meskipun proses fermentasi dan pengeringan memerlukan waktu beberapa hari, namun dalam satu hari dapat dilakukan proses produksi secara keseluruhan dengan memanfaatkan hasil fermentasi pada hari sebelumnya.

Keseluruhan kegiatan produksi dalam satu hari membutuhkan tenaga kerja sebanyak 4 HOK. Nilai koefisien tenaga kerja didapatkan dari pembagian jumlah total hari orang kerja (HOK) selama satu hari dengan bahan baku yang digunakan selama satu hari. Nilai koefisien tenaga kerja sebesar 0,0015; nilai tersebut menunjukkan bahwa untuk memproduksi satu kilogram kulit pisang menjadi pakan ternak terfermentasi dibutuhkan tenaga kerja sebesar 0,0015 HOK.

Pakan ternak terfermentasi ini merupakan hasil dari pengolahan kulit pisang segar yang diberi perlakuan fermentasi dengan menambahkan inokulan mikroba Trichoderma viride.
Selain bahan baku berupa kulit pisang, komponen lain yang diperhitungkan sebagai sumbangan input lain adalah penggunaan bahan pendukung yang merupakan gabungan dari inokulan mikroba Trichoderma viride, gula pasir, pupuk urea dan pupuk NPK, kemasan karung/ sak ukuran 50 kilogram dan bahan bakar. Total kebutuhan sumbangan input lain per hari adalah Rp 341.451,00. Dengan kebutuhan bahan baku berupa kulit pisang per hari mencapai 2.600 kilogram, sehingga sumbangan input lain untuk setiap kilogram bahan baku sebesar Rp 131,33. Nilai produk diperoleh dari perkalian faktor konversi dengan harga produk. Nilai produk yang dihasilkan dari pengolahan kulit pisang menjadi pakan ternak terfermentasi sebesar $\mathrm{Rp} 624,81$ per kilogram. Nilai ini berarti bahwa setiap pengolahan satu kilogram kulit pisang akan menghasilkan nilai pakan ternak terfermentasi sebesar Rp 624,81.

Nilai tambah merupakan hasil pengurangan nilai produk dengan harga bahan baku kulit pisang dan sumbangan input lain per kilogram bahan baku. Nilai tambah yang diperoleh pengolah adalah Rp393,48 per kilogram dengan rasio nilai tambah sebesar 62,98\%, artinya dari Rp393,48 per kilogram nilai produk maka $62,98 \%$ merupakan nilai tambah dari pengolahan produk. Besarnya nilai tambah karena proses pengolahan didapat 
dari pengurangan biaya bahan baku dan input lain terhadap nilai produksi yang dihasilkan tidak termasuk tenaga kerja, sehingga nilai tambah merupakan imbalan bagi tenaga kerja dan pendapatan pengolah.

Berdasarkan analisis nilai tambah ini diperoleh marjin dari pengolahan pakan ternak terfermentasi. Marjin ini merupakan selisih harga atau nilai produk dengan nilai input bahan baku. Marjin ini kemudian didistribusikan menjadi imbalan tenaga kerja, sumbangan input lain, dan pendapatan perusahaaan. Marjin yang diperoleh dari setiap penjualan satu kilogram pakan ternak terfermentasi adalah Rp 524,81 per kilogram. Marjin yang didistribusikan untuk tenaga kerja adalah $\operatorname{Rp} 73,85$ per kilogram atau sebesar 14,07\%. Marjin untuk sumbangan input lain sebesar Rp 131,33 per kilogram atau sebesar 25,02\%, sedangkan marjin untuk pendapatan usaha adalah $\mathrm{Rp} 319,63$ per kilogram atau sebesar $60,91 \%$, yang merupakan imbalan bagi perusahaan atas penggunaan modal, aktiva dan manajemen. Marjin pendapatan perusahaan yang lebih besar daripada marjin imbalan tenaga kerja menunjukkan bahwa industri pengolahan pakan ternak terfermentasi merupakan usaha yang padat modal. Usaha padat modal yang dimaksud adalah usaha yang telah dilengkapi oleh mesin-mesin produksi mekanis sehingga tidak membutuhkan tenaga kerja yang terlalu banyak.

Agroindustri pakan ternak terfermentasi memberikan nilai tambah positif untuk setiap kilogram bahan baku yang digunakan, yaitu sebesar Rp 393,48 atau $62,98 \%$ dari nilai produk. Besaran nilai tambah ini dipengaruhi oleh beberapa faktor, antara lain jumlah input bahan baku dan output yang dihasilkan, harga bahan baku dan produk akhir yang dipasarkan, serta sumbangan input lain yang mendukung proses pembuatan pakan ternak terfermentasi. Marjin balas jasa untuk penggunaan input lain pada agroindustri pakan ternak terfermentasi sebesar $25,02 \%$. Untuk pembuatan pakan ternak terfermentasi hanya membutuhkan sumbangan input lain untuk proses aktivasi mikroba dengan jumlah yang sedikit dan harganyapun tidak terlalu mahal.

Berdasarkan perhitungan balas jasa untuk faktor produksi, agroindustri pakan ternak terfermentasi memberikan marjin untuk pendapatan perusahaan lebih besar dibandingkan marjin pendapatan untuk tenaga kerja. Untuk usaha pakan ternak terfermentasi, 
perusahaan memperoleh marjin pendapatan sebesar $60,91 \%$, sedangkan tenaga kerja memperoleh marjin pendapatan sebesar 14,07\%. Hal ini menunjukkan bahwa usaha tersebut merupakan usaha padat modal yang tidak membutuhkan tenaga kerja terlalu banyak karena telah dilengkapi oleh mesin-mesin produksi mekanis.

\section{KESIMPULAN}

1. Agroindustri pakan ternak terfermentasi menguntungkan dan efisien untuk diusahakan berdasarkan analisis pendapatan dan nilai $\mathrm{R} / \mathrm{C}$ ratio, yaitu pendapatan agroindustri pakan ternak terfermentasi untuk produksi setiap hari sejumlah $\mathrm{Rp}$ $567.179,00$ dengan nilai $\mathrm{R} / \mathrm{C}$ ratio 1,54 .

2. Agroindustri pakan ternak terfermentasi memberikan nilai tambah positif untuk setiap kilogram bahan baku yang digunakan, yaitu sebesar $\mathrm{Rp}$ 393,48 atau $62,98 \%$ dari nilai produk.

\section{DAFTAR PUSTAKA}

Badan Pusat Statistik Kabupaten Lumajang. 2015. Kecamatan Senduro Dalam Angka 2015. Lumajang: BPS Kabupaten Lumajang.

Gubernur Jawa Timur. 2012. Peraturan Gubernur Jawa Timur Nomor 72 Tahun 2012 Tentang Upah Minimum Kabupaten/ Kota di Jawa Timur Tahun $2013 . \quad$ http://disnakertransduk. jatimprov.go.id. Diakses pada tanggal 05 Maret 2013.

Hayami, Y., Kagawoe, T., Morooka, Y., dan Siregar, M. 1987. Agriculture Marketing and Processing in Untad Java Perspective from Sunda Village. Bogor: CGPRT Centre.

Manulang, K. 1990. Pengukuran Produktivitas dengan Metode Nilai Tambah. Jakarta: Pusat Produktivitas Nasional.

Santoso, H. B. 1995. Sale Pisang. Yogyakarta: Penerbit Kanisius.

Soekartawi. 2002. Analisis Usahatani. Jakarta: UI Press.

Sukria, H.A. dan Krisnan, R. 2009. Sumber dan Ketersediaan Bahan Baku Pakan di Indonesia. Bogor: IPB Press.

Udjianto, A. 2003. "Peluang Pemanfaatan Limbah Pisang Sebagai Pakan Ternak". Prosiding Temu Teknis Fungsional Non Peneliti. Bogor: Balai Penelitian Ternak.

Udjianto, A., Rostiati, E. dan Purnama, R.D. 2005. "Pengaruh Pemberian Limbah Kulit Pisang Fermentasi Terhadap Pertumbuhan Ayam Pedaging dan Analisa Usaha". Prosiding Temu Teknis Nasional Tenaga Fungsional Pertanian. Bogor: Balai Penelitian Ternak. 